\title{
Economic Effects of Consolidations of Publishers and Newspapers in the Netherlands
}

Citation for published version (APA):

van Kranenburg, H. L. (2001). Economic Effects of Consolidations of Publishers and Newspapers in the Netherlands. Journal of Media Economics, 14(2), 61-76. https://doi.org/10.1207/S15327736ME1402_01

Document status and date:

Published: 01/01/2001

DOI:

10.1207/S15327736ME1402_01

Document Version:

Publisher's PDF, also known as Version of record

\section{Please check the document version of this publication:}

- A submitted manuscript is the version of the article upon submission and before peer-review. There can be important differences between the submitted version and the official published version of record.

People interested in the research are advised to contact the author for the final version of the publication, or visit the DOI to the publisher's website.

- The final author version and the galley proof are versions of the publication after peer review.

- The final published version features the final layout of the paper including the volume, issue and page numbers.

Link to publication

\footnotetext{
General rights rights.

- You may freely distribute the URL identifying the publication in the public portal. please follow below link for the End User Agreement:

www.umlib.nl/taverne-license

Take down policy

If you believe that this document breaches copyright please contact us at:

repository@maastrichtuniversity.nl

providing details and we will investigate your claim.
}

Copyright and moral rights for the publications made accessible in the public portal are retained by the authors and/or other copyright owners and it is a condition of accessing publications that users recognise and abide by the legal requirements associated with these

- Users may download and print one copy of any publication from the public portal for the purpose of private study or research.

- You may not further distribute the material or use it for any profit-making activity or commercial gain

If the publication is distributed under the terms of Article $25 \mathrm{fa}$ of the Dutch Copyright Act, indicated by the "Taverne" license above, 


\title{
Economic Effects of Consolidations of Publishers and Newspapers in The Netherlands
}

\author{
H. L. (Hans) van Kranenburg \\ Department of Management Sciences/Strategy \\ Maastricht University
}

\begin{abstract}
The aim of this article is to assess, by way of an empirically based analysis, whether or not the price behavior of newspapers, both on reader and advertising markets, is affected by consolidation. Two questions related to consolidation are investigated. The first relates to the extent to which consolidation between regional newspapers in the same area leads to a change in either the subscription price or in the real advertising costs. The second investigates whether a merger between newspaper publishing companies leads to a change in the subscription price of their newspapers or in the real advertising costs. Newspapers that were directly or indirectly involved in consolidations did not show a more detrimental pricing behavior to consumers than the other dailies.
\end{abstract}

The continuing decline in the number of competing newspapers and publishers and the significant increase of newspaper publishers owning two or more daily newspapers are frequently cited as evidence of a deteriorating competitive situation in this industry and of the need for corrective government action, especially by the antitrust authorities in various countries. Though there is concern in the general public about the consequences of the upsurge in concentration, the social implications of increasing concentration in the newspaper industry are ambiguous.

Economists, legal scholars, and other professionals related to this industry do not agree on the effect of mergers in the market. One group emphasizes that the need for greater efficiency in a dynamic market leads to consolidations that facilitate, for example, the achievement of economics of scale. The other group, how-

Requests for reprints should be sent to H. L. van Kranenburg, Maastricht University, FDEWB-MW/Strategy, P.O. Box 616, 6200 MD Maastricht, The Netherlands. E-mail: h.vankranenburg@mw.unimaas.nl 
ever, points to the resulting reduction in competition and potential abuse of monopoly power, leading to price increases that are detrimental to consumers (e.g., Albarran \& Dimmick, 1996; Brennan, 1990; Fox \& Halverson, 1979).

Many studies are concerned with the influence mergers and acquisitions have on market power in newspaper industries. In this context, researchers have considered the pricing behavior of newspapers under various market and ownership conditions. These studies provide important insights into the behavior of newspapers resulting in possible violations of the antitrust legislation. Studies considering the effect of competition on subscription and advertising prices are not conclusive. For instance, Grotta (1971) and Kerton (1973) showed that competing newspapers had lower prices, although other studies of competing and monopoly newspapers found that monopolists had lower prices than competing newspapers (Chaudri, 1995; Picard, 1986, 1988).

Another group of studies examined the relation between conglomerate ownership and the price behavior of daily newspapers. For instance, Blankenburg (1983, 1995), Busterna (1991), and Ferguson (1983) found that chain ownerships charge higher prices. Mathewson (1972) and Owen (1973), however, found no positive relationship. There is no convincing evidence that group ownership confers market power. These price behavior results can be explained by the localized structure of competition in the industry (e.g., Bucklin \& Caves, 1989; Hagner, 1983; Lacy \& Davenport, 1994; Rosse, 1978).

Only a few studies have investigated the effects of newspaper industry mergers and acquisitions in the Netherlands, even though the daily newspaper market in the Netherlands has also shown substantial structural changes over recent years (e.g., Cuilenburg, Kleinnijenhuis, \& Ridder, 1988; Ridder, 1984). Ownership has become more concentrated, and exit from the industry seems to almost invariably take the form of a merger or takeover. No study investigated the impact of concentration on the price setting of newspapers in the Netherlands. Recently, the increasing concentration within the newspaper industry has been criticized by the Dutch antitrust authority (Nederlandse Mededingingsautoriteit [NMa]), which has argued that consolidation leads to higher prices paid by readers and advertisers. However, the antitrust authority did not take into account the dual nature of the industry. Furthermore, it did not show evidence that the pricing behavior of newspapers that are directly or indirectly involved in a merger or acquisition is indeed detrimental to consumers after the consolidation.

The aim of this article is to assess, by way of an empirically based analysis, whether or not the price behavior of newspapers, both on reader and advertising markets, is affected by consolidation. The study investigates two questions related to consolidation. The first relates to the extent to which a merger between two or more regional newspapers in the same geographic area leads to a change in either the subscription price of the consolidated newspaper or in the real advertising costs. The second question investigates whether a merger between newspaper pub- 
lishing companies leads to a non-consumer-friendly change in the subscription price of their newspapers or in the real advertising costs. In this context, an examination is also made to determine whether or not high-circulation regional newspapers have lower advertising costs than low-circulation newspapers.

\section{ANTITRUST INVESTIGATION ISSUES}

The analysis of competition in antitrust investigations often takes the form of seeking to establish the effects of a particular set of actions or a change in behavior. This is the case when a merger of companies in the same market leads to a change in output, quality, or price to the detriment of consumers. Therefore, the antitrust analyses have to focus on a two-fold test (Bellamy \& Child, 1993). The first part must examine whether the consolidation leads to a creation or strengthening of a dominant position. Consequently, the following question arises: Does the new situation significantly impede effective competition through high concentration?

Regulatory intervention by the antitrust authority is, then, only desirable if there is evidence that competitive constraints are absent or are removed by a concentration event. If no relation between concentration and prices can be found, then this is an indication that the players are still acting in a competitive market. Where competition still exists, there is no ground for intervention. If increased concentration has come about because of the superior efficiency of firms that have become large, then an antimerger policy courts the danger of reducing efficiency. The reduction in efficiency is caused either by discouraging innovative activities of firms or by shifting output to smaller, less efficient firms (Demsetz, 1973).

The newspaper industry case is more complicated than the standard joint products framework because the newspaper's pricing decisions are confounded by the posited demand interdependence of its two products that are sold in two different markets. Copies of the newspaper are sold to the readers and advertising space is sold to advertisers. A change in either the volume of advertising or in the level of circulation will not only directly affect the other variable, but it will also set off several rounds of effects as the resulting change in one variable brings about a further change in the other. This process is known as demand interdependence (e.g., Busterna, 1988a, 1988b; Ferguson, 1983; Rosse, 1967, 1978; Thompson, 1989). Therefore, standard neoclassical arguments against monopolies being welfare reducing from a social viewpoint may not hold because of the duality in product space.

Chaudhri (1998) shows that the special duality structure of the newspaper can render the conventional neoclassical wisdom about monopoly pricing incorrect. It is established, under varying assumptions regarding market structure in each of the newspaper's product markets, that the circulation nature of the industry renders a counterintuitive price response in the market for newspapers. In a concentrated newspaper market, the newspaper decides to lower the price for its copies, which 
increases circulation and, hence, results in increased advertising revenue. If competition from other media exists, a newspaper in a concentrated market has to set its price equal to the competitive price. Empirical investigations support this theory. For instance, a causal investigation of the pricing behavior of the newspaper at the use of monopoly power reveals that in all the markets in Australia the circulation price did not rise after exit from the industry by a competitor. In fact, Chaudhri (1995) showed that the monopolist prices are even below marginal cost in the reader market in Australia.

In the case of the Dutch newspaper industry, it also is important to know that the standard neoclassical arguments against consolidation being welfare reducing from a consumer viewpoint may not hold because of the duality in product space. The antitrust authority decision therefore has to rely on economic analysis and empirical verification. In particular, empirical analysis of economic issues is increasingly becoming an essential feature of major antitrust investigations in the newspaper industry.

There are a number of ways in which the relation between consolidation and behavior such as price setting can be empirically assessed. The main determinant of the method of analysis is the availability of adequate data. It is essential to use real data and information from the newspaper industry. There is no single quantitative technique that is designed to capture the historical impact of an event. However, an event-history analysis is an adequate method to study the relation between consolidation and firms' behavior. A detailed historical profile of the industry can better explain the processes in the industry and their effects than would be possible in a solely static analysis.

\section{DAILY NEWSPAPER INDUSTRY IN THE NETHERLANDS}

Since the Second World War, the number of daily newspapers and publishers in the Netherlands has experienced a continuous decline. Concentration has been a dominating trend in the market. In the ongoing tendency of large-scale economies, growth depends crucially on limited heterogeneous resources such as reading audiences. Newspapers have become larger and more general, stimulating competition in the market. In 1950, for instance, 60 independent publishers were selling 112 daily newspapers with a total circulation of 2.78 million, but in 1990, 21 independent publishers were selling only 78 dailies with a total circulation of 4.59 million. The number of daily newspapers and newspaper publishing companies had further declined to 53 (with a total circulation of 4.75 million) and 13 respectively in 1997. By 2000, 52 dailies were published by only eight publishing companies, of which the largest three have a market share of $89.5 \%$. These three, N.V. Holding Maatschappij De Telegraaf, PCM-Uitgevers, and Wegener N.V. have market shares of $30.0,30.8$, and $28.7 \%$ respectively. 
In the 1990s more than 25 consolidations involving more than 60 Dutch regional daily newspapers took place. Because of the increasing importance of economies of scale, the minimum efficient scale of a regional newspaper or a group of newspapers increased from 40,000 to more than 100,000 copies in the last four decades (Kranenburg, 1999). This resulted in a trend toward mergers and acquisitions, which has fueled the concentration process.

When analyzing the economic effects of consolidation, it is important to recognize two important structural conditions in the industry. First, since 1962 government-mandated price increases were pervasive in the industry. As a result, a price change analysis has to be weighted against industry average increases. Second, within-industry competition affected the pricing behavior of regional daily newspapers. Both of these factors influence the methodology and are therefore discussed following.

\section{Impact of Historical Price-Increase Regime on the Analysis}

Unlike the vast majority of industries, the newspaper industry is intimately linked to the protection of freedom of expression. Revenues and costs play a crucial role in the determination of the independent survival opportunities of individual newspapers and publishing companies. Since World War II, the total production costs of newspapers have increased dramatically. Many newspapers and publishers, generally small ones, have had difficulties maintaining financial independence. To ensure the economic independence of newspapers, the Dutch government intervened in the industry with regulations and financial support. The daily newspaper market in the Netherlands can therefore be described as an imperfect market.

In 1962 the Dutch government imposed a rigid price policy for daily newspapers through a tight link between subscription prices and advertising tariffs (Dutch Newspaper Publishers' Association [NDP] annual reports). Since then, newspapers have been required to annually increase subscription prices and advertising tariffs by a minimum percentage agreed on by all publishers. Each year the members of the Dutch Newspaper Publishers' Association negotiate the necessary price increases. All newspapers and publishers have to agree; otherwise, no price increase takes place unless the government forces the newspapers to increase their prices by a small percentage to guarantee the multiformity in the daily newspaper market. The increases are subject to government approval. The collective price policy of the Dutch Newspaper Publishers' Association and the Dutch government has restricted the possibility of newspapers to compete on subscription prices or advertising tariffs. Of course, newspapers could increase prices more than the obliged minimum levels of annual price growth, although a disproportional growth in prices of particular newspapers could result in a loss of subscribers. Because of the increasing pressure from the European Commission to forbid cartels, 
the price policy for the newspaper market is disappearing gradually. Probably by 2003 no dispensation will be given to the newspaper industry anymore.

Kranenburg (1999) showed that the average annual real prices of newspapers increased after 1970 because of this cost-based pricing rule imposed by law. This pattern of increasing average prices implies that the production costs increased as well, because newspaper costs and revenue components are highly correlated at the aggregate level. ${ }^{1}$

\section{Impact of Competition From National Daily Newspapers}

Nationally oriented and large-scale newspapers have become more pronounced in the Dutch daily newspaper industry. Kranenburg (1999) showed the outcome of the competitive process in terms of transfer of market shares from losers to winners. The results show that regional daily newspapers are losing readers to national daily newspapers. Regional daily newspapers have lost about $15 \%$ market share of the reader market to Dutch national dailies in the last two decades. To survive, regional newspapers set their subscription price lower than the national dailies. Figure 1 plots the average annual subscription price development of regional and national dailies between 1980 and 1997. This graph shows that

\footnotetext{
${ }^{1}$ The correlation between revenue and costs of newspapers in the Netherlands is 0.99 .
}

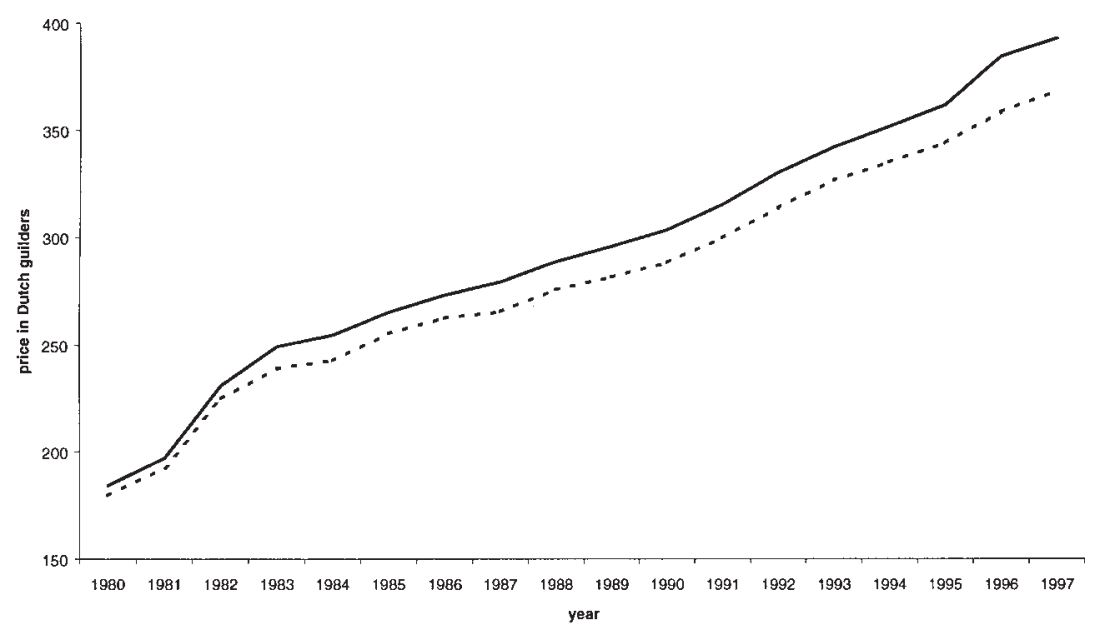

Price national dailies ...... Price regional dailies

FIGURE 1 Development of subscription price of national and regional dailies. 
the average annual subscription price of regional dailies increased at a lower growth rate than that of the national daily newspapers.

Although the regional daily prices are limited by national daily prices, the Dutch antitrust authority expects that the regional daily newspapers that are directly or indirectly involved in consolidation will show a more detrimental pricing behavior toward consumers than do the other regional dailies. Hence, an empirical analysis is needed to test the impact of consolidation on the pricing behavior of regional newspapers. Therefore, it is necessary to compare the behavior of regional dailies that in one way or another have been involved in a consolidation to the behavior of all other regional daily newspapers.

\section{METHOD}

Data for this study were supplied by the Dutch Bureau for Newspaper Publicity (CEBUCO), the Dutch Central Bureau of Statistics (CBS), and the publishers Wegener N.V. and N.V. Holding Maatschappij De Telegraaf. CEBUCO provided information on publishers, circulation, advertising tariffs, and subscription price for each daily newspaper. These data were complemented by individual newspaper data from the Wegener N.V. marketing department and N.V. Holding Maatschappij De Telegraaf for some daily newspapers. The CBS provided information on the consumer price index figures. For information about all mergers, incorporations, and takeovers that occurred between 1987 and 1997, the author consulted reports published by the newspaper publishing companies themselves, newspapers, and specialized books that report on business events.

Data for the first part of the study, involving an analysis of regional daily newspapers, were collected for 35 regional daily newspapers that were directly involved in a merger or an incorporation or acquisition between two or more regional newspapers in the Netherlands after 1987. From these 35 dailies, only 18 daily newspapers survived after consolidation. The sample of exiting newspapers contains about $60 \%$ of all disappearing dailies in the investigating period. In general, a merger takes place between more or less equally sized newspapers, and an incorporation or acquisition between newspapers that differ significantly in size. A merger indicates that a newspaper merged with one or more newspapers (titles) and a new title results.

An incorporation means that the smaller newspaper is absorbed by the larger newspaper and loses its identity or title. In this case, the same publishing company prints these newspapers. A newspaper can also absorb a newspaper that is printed by another publishing company. This is called an acquisition. In this study acquisitions and incorporations are treated as the same type of event. For the second part of the study, involving consolidations among newspaper publishing companies, historical data are available for seven consolidations involving 23 daily regional 
newspapers. This sample contains the majority of the consolidations of publishing companies that took place in the investigation period.

The method of research is an event-history approach. The event-history study aims to provide empirical evidence that can answer the antitrust questions by comparing growth rates of subscription prices and advertising costs per 1,000 copies of newspapers before and after consolidation occurred. This analysis also is capable of dealing with the time effect. Namely, has the market power of publishers and newspapers, both on reader and advertising markets, increased substantially in succeeding years? If market power has increased and the parties did use that power, then it is expected that their pricing behavior in the following years will be more detrimental to consumers and advertisers than that of the other newspapers. If, however, this effect cannot be found, then this is an indication of the existence of competitive constraints.

To compare the subscription prices and advertising costs before and after the consolidation, the values were corrected for inflation using the consumer price index (CPI). ${ }^{2}$ It is important to recognize the role that audience size (i.e., circulation) plays in setting advertising tariffs. This study therefore employed the standard of "cost per thousand," where advertising tariffs are based on circulation.

The effect of the collective price policy that started in the 1960s was that the subscription price of all newspapers increased. Thus, to measure the effect of consolidation on the subscription price, it is necessary to compare the growth rate of the annual subscription price of the involved daily newspaper or newspapers to the industry average growth rate of the subscription price of all other regional daily newspapers. If increased concentration leads to the expected abuse of market power then, in general, the growth in annual subscription price of the involved newspaper or newspapers should be higher than the industry average price growth level of regional newspapers. The same is true for the advertising costs.

\section{RESULTS}

The empirical analysis is split into two parts. The first examines the effects of the mergers and incorporations of regional newspapers on subscription prices and advertising costs of the surviving paper. In general, the involved newspapers belonged to the same publishing company. The second part of the historical analysis deals with the impact of an acquisition or a merger between newspaper publishing companies on subscription prices and advertising costs of newspapers belonging to

\footnotetext{
${ }^{2}$ Because both consumers and producers read newspapers and buy advertising space in a daily newspaper, it is appropriate to consider the CPI (based on the purchasing power of consumers) when deflating subscription prices and advertising tariffs.
} 
these companies. These regional newspapers did not belong to the same publishing company before the consolidation.

\section{Effects of Regional Daily Newspaper Consolidation}

The antitrust subquestion that has to be answered is whether or not the consolidated regional newspaper exhibited a detrimental pricing behavior in comparison to the other established regional newspapers in the Netherlands. Table 1 shows the percentage of consolidated newspapers that increased their subscription price more, less, or equal to the industry average annual subscription price increase of regional dailies the first five years succeeding the consolidation.

On average, the subscription price of the consolidated newspaper does not increase faster than that of the other regional newspapers. The majority of the annual increases are actually below the regional level. The results indicate that in 40 to $89 \%$ of these cases the annual growth in subscription prices of the consolidated newspapers increased less that the average growth level of all other regional newspapers in the industry. These results do not exhibit a systematic relation between consolidation and a more detrimental pricing behavior to consumers. Indeed, on average, consolidated newspapers increased their prices less than the industry averages. The average annual difference in price growth rates between the consolidated regional daily newspapers and all dailies in The Netherlands is -0.42984 , and that between the consolidated regional dailies and all other regional daily newspapers is still -0.02961 . This also is evidence that the consolidated regional daily newspapers generally had a more consumer-friendly pricing behavior. The evidence of no apparent negative impact on prices for consumers is a first signal of an absence of the assumed market power impact on prices due to consolidation.

TABLE 1

Share of Consolidated Regional Dailies That Have Adjusted Their Subscription Price Relative to the Average Price Level Increase of All Regional Daily Newspapers in the Years Following Consolidation

\begin{tabular}{|c|c|c|c|c|c|c|c|c|c|c|}
\hline \multirow{2}{*}{$\begin{array}{l}\text { Subscription Price } \\
\text { Increase }\end{array}$} & \multicolumn{2}{|c|}{ Year 1} & \multicolumn{2}{|c|}{ Year 2} & \multicolumn{2}{|c|}{ Year 3} & \multicolumn{2}{|c|}{ Year 4} & \multicolumn{2}{|c|}{ Year 5} \\
\hline & $\%$ & $n$ & $\%$ & $n^{a}$ & $\%$ & $n$ & $\%$ & $n$ & $\%$ & $n$ \\
\hline Higher & 16.67 & 3 & 25.00 & 4 & 43.75 & 7 & 60.00 & 9 & 0.00 & 1 \\
\hline Lower & 83.33 & 15 & 75.00 & 12 & 56.25 & 9 & 40.00 & 6 & 88.89 & 8 \\
\hline Equal & 0.00 & - & 0.00 & - & 0.00 & - & 0.00 & - & 0.00 & - \\
\hline
\end{tabular}

aThe number of cases declined over time because for a few cases the consolidation took place during the last 5 years of the investigation period, therefore data are not available yet, or the consolidated newspaper was involved in a new consolidation within 5 years. 
Table 2 shows the percentage of consolidated newspapers that had higher, lower, or equal advertising costs for the first 5 years after the event, in comparison to the weighted average advertising costs of the involved newspapers before the consolidation. ${ }^{3}$

This table shows that in 70 to $92 \%$ of the cases, the advertising costs (adjusted for inflation) of the consolidated newspapers were equal to or lower than the weighted average real advertising costs before the consolidation of the involved newspapers. This indicates that the advertiser interested in media contacts benefits from the consolidation. It is clear that a higher concentration in the specific area does not automatically lead to higher advertising costs. This result may imply the existence of competition from national newspapers and other advertising media. It is worthwhile to consider the possibility that after a merger or incorporation the remaining newspaper might lose readers, which would tend to drive up its advertising costs per thousand. However, because there is a general downward tendency, any lost readership is far outweighed by the other forces driving down costs. It can be concluded that mergers and incorporations of newspapers do not explicitly result in higher prices and exploitation of potential competitive power as expected by the antitrust authority.

\section{Effects of Consolidation Between Newspaper Publishing Companies}

Table 3 shows the percentage of newspapers that increased their subscription price more, less, or equal to the industry average annual increase in subscription price of all regional daily newspapers during the first 5 succeeding years after the consolidation of their publishing companies. These results suggest that the consolidation of publishing companies in the market did not lead to a larger change in their newspaper prices than otherwise would have been the case. Fifty to $83 \%$ of the newspapers owned by the consolidated publisher had a lower annual subscription price increase than the industry average of all other regional newspapers. If the acquisition or merger between publishers should increase concentration, then, in general, the Dutch antitrust authority expects that the surviving publisher will increase its market power resulting in a negative impact on prices for consumers. However, this finding shows that even with an increase in concentration or number of newspapers owned by the consolidated publishing company, prices generally increase at a lower rate than the average for regional dailies in the industry. In other words, it

${ }^{3}$ Weighted advertising costs per 1000 readers is defined as follows:

$$
\sum_{i=1}^{N}\left[\text { Circulation }_{i, t-1} /\left(\sum_{j=1}^{N} \text { Circulation }_{j, t-1}\right) * \text { Real Advertising tariff }_{i, t-1}\right]
$$

with $i$ and $j$ denoting newspaper $\mathrm{i}$ and $\mathrm{j}$ respectively, and $t$ is time period. 
TABLE 2

Share of Consolidated Regional Daily Newspapers That Have Adjusted Their Advertising Costs Per 1000 Readers in the Years Following the Consolidation in Comparison to the Weighted Average Advertising Costs of the Newspapers Before Consolidation

\begin{tabular}{|c|c|c|c|c|c|c|c|c|c|c|}
\hline \multirow{2}{*}{$\begin{array}{l}\text { Advertising Costs } \\
\text { Increase }\end{array}$} & \multicolumn{2}{|c|}{ Year 1} & \multicolumn{2}{|c|}{ Year 2} & \multicolumn{2}{|c|}{ Year 3} & \multicolumn{2}{|c|}{ Year 4} & \multicolumn{2}{|c|}{ Year 5} \\
\hline & $\%$ & $n^{a}$ & $\%$ & $n$ & $\%$ & $n$ & $\%$ & $n$ & $\%$ & $n$ \\
\hline Higher & 8.33 & 1 & 9.09 & 1 & 27.27 & 3 & 30.00 & 3 & 20.00 & 1 \\
\hline Lower & 66.67 & 8 & 72.73 & 8 & 63.64 & 7 & 70.00 & 7 & 80.00 & 4 \\
\hline Equal & 25.00 & 3 & 18.18 & 2 & 9.09 & 1 & 0.00 & - & 0.00 & - \\
\hline
\end{tabular}

aThe number of newspapers is less than 18 because not all advertising tariffs of newspapers were publicly available.

TABLE 3

Share of Regional Daily Newspapers Printed by Consolidated Publishers That Have Adjusted Their Subscription Price Relative to the Average Price Level Increase of All Regional Newspapers in the Years Following Consolidation

\begin{tabular}{|c|c|c|c|c|c|c|c|c|c|c|}
\hline \multirow{2}{*}{$\begin{array}{l}\text { Subscription } \\
\text { Price Increase }\end{array}$} & \multicolumn{2}{|c|}{ Year 1} & \multicolumn{2}{|c|}{ Year 2} & \multicolumn{2}{|c|}{ Year 3} & \multicolumn{2}{|c|}{ Year 4} & \multicolumn{2}{|c|}{ Year 5} \\
\hline & $\%$ & $n$ & $\%$ & $n$ & $\%$ & $n$ & $\%$ & $n$ & $\%$ & $n$ \\
\hline Higher & 17.39 & 4 & 39.13 & 9 & 30.43 & 7 & 38.89 & 7 & 50.00 & 7 \\
\hline Lower & 82.61 & 19 & 60.87 & 14 & 69.57 & 16 & 61.11 & 11 & 50.00 & 7 \\
\hline Equal & 0.00 & - & 0.00 & - & 0.00 & - & 0.00 & - & 0.00 & - \\
\hline
\end{tabular}

seems that publishers did not use their increased concentration to increase subscription prices of their daily newspapers above the industry average level of regional daily newspapers.

Table 4 shows the percentage of newspapers that were printed by a publishing company that was involved in an acquisition or a merger with other publishers that had a lower or equal growth rate of their advertising costs in comparison to the industry average during the first 5 years after the consolidation took place.

The results illustrate that in 33 to $64 \%$ of the cases studied, advertising costs (adjusted for inflation) of the involved regional newspapers increased equally or less than the annual industry average level after the merger or acquisition involving their publishing company. There is no clear evidence to confirm a relation between increasing advertising costs and the increased concentration of the publishing companies. It is expected that consolidations in the Dutch daily newspaper industry are generally motivated by more efficient operations, rather than by use of market power. 
Also examined in this study was whether high-circulation newspapers have lower advertising costs than the low-circulation newspapers. Table 5 shows the relation between advertising costs per 1000 readers and the size of the newspaper between 1990 and 1997. Advertising combinations of regional newspapers are included in this analysis.

The results in Table 5 illustrate that the newspaper's advertising costs per 1000 readers is negatively related to the circulation of the newspaper. The larger the circulation, the lower the advertising costs per 1000 readers; this is similar to the findings of Picard (1998). This finding demonstrates that despite the upsurge in concentration in the daily newspaper industry in the Netherlands, the incumbent newspapers and the newspaper publishers did not show evidence of explicit market power abuse. Advertisers actually benefit from increasing circulation because their advertisements reach more people at a lower price per issue.

TABLE 4

Share of Regional Daily Newspapers Printed by Consolidated Publishers That Have Adjusted Their Advertising Costs (Adjusted for Inflation) per 1000 Readers Compared to the Industry Average Level in the Years Following Consolidation

\begin{tabular}{|c|c|c|c|c|c|c|c|c|c|c|}
\hline \multirow{2}{*}{$\begin{array}{l}\text { Advertising Costs } \\
\text { Increase }\end{array}$} & \multicolumn{2}{|c|}{ Year 1} & \multicolumn{2}{|c|}{ Year 2} & \multicolumn{2}{|c|}{ Year 3} & \multicolumn{2}{|c|}{ Year 4} & \multicolumn{2}{|c|}{ Year 5} \\
\hline & $\%$ & $n^{a}$ & $\%$ & $n$ & $\%$ & $n$ & $\%$ & $n$ & $\%$ & $n$ \\
\hline Higher & 35.71 & 5 & 42.86 & 6 & 57.14 & 8 & 66.67 & 8 & 37.50 & 3 \\
\hline Lower & 57.14 & 8 & 57.14 & 8 & 35.71 & 5 & 33.33 & 4 & 62.50 & 5 \\
\hline Equal & 7.15 & 1 & 0.00 & - & 7.15 & 1 & 0.00 & - & 0.00 & - \\
\hline
\end{tabular}

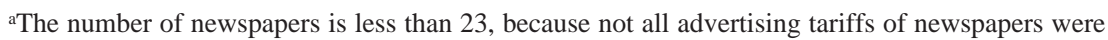
publicly available. Furthermore, the number of cases declined over time because, for a few cases, the following years do not exist in the investigation period.

TABLE 5

Advertising Costs (Adjusted for Inflation) per 1000 Readers in Comparison to the Size of the Newspaper Bewteen 1990 and 1997

\begin{tabular}{lc}
\hline Size & $\begin{array}{c}\text { Real Advertising Costs per 1000 Readers } \\
\text { in Dutch Guilders }\end{array}$ \\
\hline$<10,000$ & 1.91 \\
$10,000-50,000$ & 0.87 \\
$50,000-100,000$ & 0.50 \\
$100,000-150,000$ & 0.48 \\
$150,000-200,000$ & 0.47 \\
$200,000>$ & 0.41 \\
\hline
\end{tabular}




\section{DISCUSSION}

Empirical analysis of economic issues is an essential feature of many antitrust investigations. An antitrust investigation of competition in the media should take the form of seeking to establish the effects of a particular set of actions or a change in behavior. This is the case when a consolidation like a merger or an acquisition in the market may lead to a larger change in output, quality, or price than otherwise would have been the case.

In this study it was found that newspapers involved in consolidation did not show a more detrimental price behavior toward consumers than did the other newspapers. The evidence of the absence of a systematic positive relation between increasing concentration in the regional daily newspaper market in the Netherlands and subscription prices and advertising costs is strong. The findings reject the expected outcome of the neoclassical approach regarding increasing concentration in the daily newspaper market and the associated higher price settings. In fact, the results point mainly in the opposite direction: Consolidation tends to be associated with the same or even more consumer-friendly pricing behavior of the involved newspapers both on the reader market and the advertising market. The evidence suggests the existence of intensive competition from within and outside the daily newspaper market. Where exactly the competitors come from and what mechanism keeps the prices in check cannot be fully explained in this study. Of course, regional daily newspapers experience increasing competition from nationally oriented daily newspapers. Technological changes, such as the increase in transportation possibilities and the improvements of electronic communication, are transforming the market structure from a geographically partitioned to a more nationwide market. There are strong indications of emerging intensity of competition between newspapers and other media sources such as local television and radio, Internet, direct mail, or outdoor advertising. There is intense competition within and outside the daily newspaper industry for the consumer's time and the advertiser's scarce discretionary money. The apparent importance of the emergence of competition in the Dutch media sector forces regional newspapers to merge with each other or to cooperate in their struggle to survive. Evidence of potential market power as a result of consolidation of regional daily newspapers or publishing companies therefore needs to be evaluated in a more widely defined market context that encompasses more than just regional daily newspapers.

\section{CONCLUSION}

The aim of the article was to explore what the consequences of consolidations are on prices for subscription and advertisements in the daily newspaper market in the Netherlands. The study provided empirical evidence that, in the context of the daily 
newspaper industry, consolidations did not result in the systematic detrimental pricing behavior toward consumers assumed by the Dutch antitrust authority. It was, however, not an attempt to explain where the competitive constraints in the industry come from and which mechanisms keep the prices in check.

The event-history analysis conducted in this study has shown that, in the case of the Dutch regional daily newspaper industry, consolidation between newspapers or publishing companies did not result in price increases to the detriment of consumers and advertisers. In fact, the evidence of the existence of a systematic negative relation between concentration in the regional daily newspaper market and prices is strong. Increasing concentration in the newspaper industry in the Netherlands does not explicitly show a creation or strengthening of the abuse of a dominant market position. This implies that there is no real reason for the antitrust authority to forbid these consolidations.

To further examine the effects of consolidation on competition in the media landscape, more empirical studies are needed. One important aspect would be the role technological developments in the communication and information industries plays in shaping the market structure. Antitrust authorities and media economic researchers may need to change how they consider markets, in particular the newspaper markets. Evidence of potential market power in the media sector needs to be evaluated in a more widely defined market that includes, among others, regional and national newspapers and other media. In doing so, antitrust authorities and researchers would be better able to analyze the potentially detrimental effects of mergers and acquisitions in the media.

\section{ACKNOWLEDGMENTS}

The author thanks the editor Alan Albarran, Jaap Feenstra of Nauta Dutilh, Britt Groosman, Thomas Hoehn of Price Waterhouse Coopers, Pauline Kuipers of Houthoff Buruma, Weijer Verloren van Themaat of Liedekerke Simeon Wessing Houthoff, and three anonymous referees for their useful comments. He also thanks the publishers N.V. Holding Maatschappij De Telegraaf and Wegener N.V. for their assistance.

\section{REFERENCES}

Albarran, A. B., \& Dimmick, J. (1996). Concentration and economies of multiformity in the communication industries. The Journal of Media Economics, 9(4), 41-50.

Bellamy, C., \& Child, G. D. (1993). Common market law of competition (4th ed.). London: Sweet \& Maxwell.

Blankenburg, W. B. (1983). A newspaper chain's pricing behavior. Journalism Quarterly, 60, 275-281. 
Blankenburg, W. B. (1995). Hard times and the news hole. Journalism \& Mass Communication Quarterly, 72, 634-641.

Brennan, T. J. (1990, Spring). Vertical integration, monopoly, and the First Amendment. The Journal of Media Economics, 3, 57-74.

Bucklin, R. E., \& Caves, R. E. (1989). Games of survival in the US newspaper industry. Applied Economics, 21, 631-649.

Busterna, J. C. (1988a). Welfare economics and media performance. The Journal of Media Economics, $1,75-88$.

Busterna, J. C. (1988b). Antitrust in the 1980s: An analysis of 45 newspaper actions. Newspaper Research Journal, 9, 25-36.

Busterna, J. C. (1991). Price discrimination as evidence of newspaper chain market power. Journalism Quarterly, 68, 5-14.

Chaudhri, V. (1995). Market structure and strategic pricing decisions in the newspaper industry: Theory and evidence [Mimeograph]. New Haven, CT: Yale University.

Chaudhri, V. (1998). Pricing and efficiency of a circulation industry: The case of newspapers. Information Economics and Policy, 10, 59-76.

Cuilenburg, J. J. van, Kleinnijenhuis, J., \& Ridder, J. A. de. (1988). Concentratie en persklimaat: Een empirisch onderzoek naar de mogelijkheid van een persbarometer. (Politikologische studies). Amsterdam: VU Uitgeverij.

Demsetz, H. (1973). Industry structure, market rivalry, and public policy. Journal of Law and Economics, 16, 1-9.

Dutch Newspaper Publishers' Association. (1950-1998). Annual reports. Amsterdam: Cebuco.

Ferguson, J. M. (1983). Daily newspaper advertising rates, local media cross-ownership, newspaper chains, and media competition. Journal of Law and Economics, 26, 635-654.

Fox, E. M., \& Halverson, J. T. (1979). Industrial concentration and the market system: Legal, economic, and social political perspectives. Chicago: American Bar Association.

Grotta, G. L. (1971). Consolidation of newspapers: What happens to the consumer. Journalism Quarterly, 48, 245-250.

Hagner, P. R. (1983). Newspaper competition: Isolating related market characteristics. Journalism Quarterly, 60, 281-287.

Kranenburg, H. L. van (1999). Entry, survival or exit of firms over industry life cycles: The daily newspaper industry in the Netherlands. Unpublished doctoral thesis, Maastricht University.

Kerton, R. R. (1973), Price effects of market power in the Canadian newspaper industry. Canadian Journal of Economics, 6, 602-606.

Lacy, S., \& Davenport, L. (1994). Daily newspaper market structure, concentration, and competition. The Journal of Media Economics, 7(3), 33-46.

Mathewson, G. F. (1972). A note of the price effects of market power in the Canadian newspaper industry. Canadian Journal of Economics, 5, 298-301.

Owen, B. M. (1973). Newspaper and television station joint ownership. Antitrust Bulletin, 18, 787-807.

Picard, R. G. (1986). Pricing in competing and monopoly newspapers, 1972-1982. LSU School of Journalism Research Bulletin,

Picard, R. G. (1988). Pricing behavior of newspapers. In R. G. Picard, J. P. Winter, M. E. McCombs, \& S. Lacy (Eds.), Press concentration and monopoly: New perspectives on newspaper ownership and operation (pp. 55-69). Norwood, NJ: Ablex.

Picard, R. G. (1998). A note on the relations between circulation size and newspaper advertising rates. The Journal of Media Economics, 11(2), 47-56.

Ridder, J. A. de. (1984). Persconcentratie in Nederland, begripsvorming, bepaling en beschrijving. Amsterdam: VU Uitgeverij.

Rosse, J. N. (1967). Daily newspapers, monopolistic competition, and economies of scale. American Economic Review, 57, 522-533. 
Rosse, J. N. (1978). The evolution of one newspaper cities (Studies in Industry Economics No. 95). Stanford, CA: Stanford University, Department of Economics.

Thompson, R. S. (1989). Circulation versus advertiser appeal in the newspaper industry: An empirical investigation. Journal of Industrial Economics, 37, 259-271. 
Copyright of Journal of Media Economics is the property of Lawrence Erlbaum Associates and its content may not be copied or emailed to multiple sites or posted to a listserv without the copyright holder's express written permission. However, users may print, download, or email articles for individual use. 